\title{
Ocena zgodności z Konstytucją przepisów ustawy o zawodach lekarza i lekarza dentysty w zakresie udostępniania pytań z egzaminów lekarskich ${ }^{1}$
}

\begin{abstract}
W stanowisku do Trybunału Konstytucyjnego Sejm wniósł o uznanie przepisów ustawy, które normują zasady udostępniania pytań z Lekarskiego Egzaminu Końcowego, Lekarsko-Dentystycznego Egzaminu Końcowego oraz Państwowego Egzaminu Specjalizacyjnego, za niezgodne z Konstytucją. Będąca autorem wniosku Naczelna Rada Lekarska stwierdziła, że pytania egzaminacyjne z przywołanych egzaminów stanowią informację publiczną, do której dostęp gwarantowany jest konstytucyjnie. W stanowisku podzielono tę konstatację i argumentację NRL, stwierdzając, że zaskarżone przepisy nie spełniają warunków zasadności ograniczenia dla ochrony porządku publicznego czy praw innych osób.
\end{abstract}

Słowa kluczowe: Trybunał Konstytucyjny, informacja publiczna, egzamin, lekarze

Assessment of constitutionality of the provisions of the Act on the Professions of Doctors and Dentists with regard to disclosing questions from medical exams: In his position the Sejm requested that the provisions of the Act which regulate the rules of disclosing questions from the Medical Final Examination, the Medical-Dental Final Examination and the State Specialization Examination, should be declared as non-conforming to the Constitution. The Supreme Medical Council, which is a claimant in the discussed case, stated that examination questions from the aforementioned exams constitute public information, to which an access is guaranteed constitutionally. The position upholds that finding and the arguments of the SMC, concluding that the provisions in question do not meet conditions justifying the restriction from the reasons of the protection of law and order or rights of other persons.

Keywords: Constitutional Tribunal, public information, exam, doctors

Doktor nauk prawnych, Katolicki Uniwersytet Lubelski Jana Pawła II, ekspert ds. legislacji BAS - kamias@kul.pl . https://orcid.org/0000-0002-1898-8980

Na podstawie art. 69 ust. $2 \mathrm{w}$ związku z art. 42 pkt 3 ustawy z dnia 30 listopada 2016 r. o organizacji i trybie postępowania przed Trybunałem Konstytucyjnym (Dz. U. poz. 2072, ze zm.), w imieniu Sejmu Rzeczypospolitej Polskiej przedkładam wyjaśnienia w sprawie wniosku Naczelnej Rady Lekarskiej z 23 marca

$1 \quad$ Projekt stanowiska Sejmu dot. wniosku Naczelnej Rady Lekarskiej z 23 marca 2017 r. (sygn. akt K 13/19), dotyczacy ustawy o zawodach lekarza i lekarza dentysty sporządzony 31 maja 2019 r.; BAS-WAKU-832/19.

Niniejsza opinia powstała $\mathrm{z}$ wykorzystaniem projektu stanowiska w sprawie K 8/15 autorstwa Wojciecha Brzozowskiego, przyjętego na posiedzeniu Komisji Ustawodawczej 18 maja 2016 r. 
2017 r. (sygn. akt K 13/19), jednocześnie wnosząc o stwierdzenie, że art. 14c ust. 4 i ust. 5 oraz art. 16 rc ust. 6 i ust. 7 ustawy z dnia 5 grudnia 1996 r. o zawodach lekarza i lekarza dentysty (t.j. Dz. U. 2019, poz. 537, ze zm.) są niezgodne z art. 61 ust. 3 w związku z art. 31 ust. 3 Konstytucji.

\section{Uzasadnienie}

\section{Przedmiot kontroli}

1. W dniu 17 kwietnia 2019 r. do Kancelarii Sejmu wpłynęło zawiadomienie Prezes Trybunału Konstytucyjnego o wszczęciu postępowania przed Trybunałem Konstytucyjnym w sprawie wniosku Naczelnej Rady Lekarskiej (dalej: NRL, wnioskodawczyni) z 23 marca 2017 r. (sygn. akt K 13/19).

Przedmiot kontroli stanowią przepisy ustawy z dnia 5 grudnia 1996 r. o zawodach lekarza i lekarza dentysty (t.j. Dz. U. 2019, poz. 537, ze zm.; dalej: u.z.1.), które normują zasady udostępniania pytań z Lekarskiego Egzaminu Końcowego (dalej: LEK), Lekarsko-Dentystycznego Egzaminu Końcowego (dalej: LDEK) oraz Państwowego Egzaminu Specjalizacyjnego (dalej: PES). Zgodnie z kwestionowanymi uregulowaniami:

a) „Testy i pytania testowe LEK i LDEK mogą być udostępnione wyłącznie osobie przystępującej do tego egzaminu, na jej wniosek, po ich wykorzystaniu w LEK lub LDEK. Dyrektor CEM udostępnia testy i pytania testowe w drodze ich okazania w siedzibie CEM. Zakazane jest wynoszenie poza siedzibę CEM udostępnianych testów i pytań testowych oraz ich reprodukowanie, kopiowanie jakąkolwiek techniką lub przepisywanie. W przypadku naruszenia tego zakazu udostępnianie zostaje przerwane. Przebieg udostępniania może być monitorowany za pomocą urządzeń rejestrujących obraz i dźwięk” (art. 14c ust. 4 u.z.l.),

b) „Udostępnieniu na zasadach określonych w ustawie z 6 września $2001 \mathrm{r}$. o dostępie do informacji publicznej podlegają wyłącznie pytania testowe wraz z poprawnymi odpowiedziami wykorzystane na potrzeby LEK albo LDEK, po upływie 5 lat od dnia przeprowadzenia tego egzaminu” (art. 14 c ust. 5 u.z.l.),

c) „Testy i pytania testowe oraz zadania i pytania egzaminu ustnego PES mogą być udostępnione wyłącznie osobie przystępującej do tego egzaminu, na jej wniosek, po ich wykorzystaniu w PES. Dyrektor CEM udostępnia testy i pytania testowe w drodze ich okazania w siedzibie CEM. Zakazane jest wynoszenie poza siedzibę CEM udostępnianych testów i pytań testowych oraz ich reprodukowanie, kopiowanie jakąkolwiek techniką lub przepisywanie. W przypadku naruszenia tego zakazu udostępnianie zostaje przerwane. Przebieg udostępniania może być monitorowany za pomocą urządzeń rejestrujących obraz i dźwięk" (art. 16rc ust. 6 u.z.l.),

d) „Udostępnieniu na zasadach określonych w ustawie $\mathrm{z}$ dnia 6 września 2001 r. o dostępie do informacji publicznej podlegają wyłącznie pytania testowe 
wraz z poprawnymi odpowiedziami wykorzystane na potrzeby PES, po upływie 5 lat od dnia przeprowadzenia tego egzaminu" (art. 16rc ust. 7 u.z.l.).

2. Odnosząc się do wyznaczonego przez wnioskodawczynię przedmiotu zaskarżenia, należy zauważyć, że w petitum wniosku NRL jako przedmiot kontroli wskazano art. 16rc ust. 6 i ust. 7 u.z.l. z uzupełnieniem, że chodzi o brzmienie nadane przez art. 1 pkt 16 lit. b ustawy z dnia 21 października 2016 r. o zmianie ustawy o zawodach lekarza i lekarza dentysty oraz niektórych innych ustaw (Dz. U. poz. 2020; dalej: ustawa zmieniająca z 2016 r.). Doprecyzowanie w petitum, że chodzi o brzmienie nadane przez ustawę zmieniającą z 2016 r. jest zbędne, gdyż nie zmodyfikowała ona wspomnianych przepisów, lecz dodała je po raz pierwszy do tekstu ustawy nowelizowanej. Nie istnieje więc wcześniejsze brzmienie art. 16rc ust. 6 i ust. 7 u.z.l., które mogłoby podlegać kontroli konstytucyjności.

Objęte zaskarżeniem przepisy dotyczą trzech rodzajów egzaminów, które można określić wspólnym mianem egzaminów lekarskich, przy czym dwa z nich (LEK i LDEK) są poddane wspólnemu reżimowi prawnemu. Przedstawienie świadectwa złożenia $\mathrm{z}$ wynikiem pozytywnym LEK lub LDEK jest jednym $\mathrm{z}$ warunków uzyskania, odpowiednio, prawa do wykonywania zawodu lekarza lub prawa do wykonywania zawodu lekarza dentysty (art. 5 ust. 4 u.z.l.). Trzeci egzamin (PES) odnosi się natomiast do kształcenia podyplomowego, a jego złożenie, poprzedzone odbyciem szkolenia specjalizacyjnego, jest wymagane od lekarza, który ubiega się o tytuł specjalisty w określonej dziedzinie medycyny (art. 16 ust. 1 pkt 2 u.z.l.).

3. Kontestowane przez NRL przepisy odnoszą się do ograniczenia dostępności testów i pytań (zadań) testowych wykorzystanych na egzaminach lekarskich (LEK, LDEK, PES) w trybie przewidzianym w ustawie z dnia 6 września $2001 \mathrm{r}$. o dostępie do informacji publicznej (t.j. Dz. U. 2018, poz. 1330, ze zm.; dalej: u.d.i.p.) oraz wskazują autonomiczny dla ustawy o zawodach lekarza i lekarza dentysty tryb udostępniania pytań (zadań) testowych.

Antycypując ustalenia co do częściowo odmiennych zasad organizacji i przeprowadzania PES w stosunku do LEK i LDEK, należy uznać, że zagadnienie prawne będące przedmiotem zainteresowania wnioskodawczyni jest w obu przypadkach co do zasady tożsame. Konstytucyjne zarzuty oraz argumenty za ich trafnością Naczelna Rada Lekarska kieruje względem zakwestionowanych przepisów en bloc, wskazując wspólne wzorce kontroli (wniosek, s. 25). Pozwala to dokonać łącznej analizy konstytucyjności zaskarżonych przepisów. Jeżeli więc w dalszym toku wywodu pojawia się odwołanie do egzaminów lekarskich, bez bliższego wskazania, to należy przez to rozumieć zarówno LEK i LDEK, jak i PES.

\section{Analiza formalnoprawna}

1. Dopuszczalność merytorycznego rozpoznania sprawy przez sąd konstytucyjny zależy od stwierdzenia braku ujemnych przesłanek procesowych. Pozostają one wspólne dla wszystkich sposobów inicjowania postępowania przed Trybunałem 
(zob. postanowienie TK z 29 kwietnia 2015 r., sygn. akt P 23/15) Zaliczają się do nich m.in.: zakaz ponownego orzekania w sprawie prawomocnie osądzonej (ne bis in idem, res iudicata), niedopuszczalność kwestionowania przed Trybunałem stosowania prawa i rozstrzygania sporów o wykładnię, pozostających poza kognicją sądu konstytucyjnego, niespełnienie wymagań formalnych pisma inicjującego postępowanie.

2. Na początku Sejm uznaje za stosowne odnieść się do legitymacji procesowej wnioskodawczyni w analizowanej sprawie.

Niniejsze postępowanie zostało zainicjowane wnioskiem pochodzącym od podmiotu o ograniczonej legitymacji procesowej. Z tego względu należy dokonać oceny realizacji konstytucyjnych przesłanek przewidzianych w art. 191 ust. 1 pkt 4 i ust. 2 Konstytucji, warunkujących skuteczne uruchomienie kontroli trybunalskiej. Wniosek w analizowanej sprawie złożyła Naczelna Rada Lekarska. Jest ona organem Naczelnej Izby Lekarskiej - jednostki organizacyjnej samorządu zawodowego lekarzy, działającej na podstawie ustawy z dnia 2 grudnia 2009 r. o izbach lekarskich (t.j. Dz. U. 2019, poz. 965; dalej: u.i.1.). W orzecznictwie Trybunału Konstytucyjnego przyjmuje się, że NRL ma status ogólnokrajowej władzy organizacji zawodowej w rozumieniu art. 191 ust. 1 pkt 4 Konstytucji (zob. wyroki TK z: 23 czerwca 2005 r., sygn. akt K 17/04; 7 października 2015 r., sygn. akt K 12/14; 7 czerwca 2016 r., sygn. akt K 8/15), co oznacza, że przysługuje jej zdolność do zainicjowania postępowania w sprawie hierarchicznej kontroli norm.

Zgodnie z Konstytucją ogólnokrajowe władze organizacji zawodowych mogą wystąpić z wnioskiem o kontrolę konstytucyjności prawa jedynie wówczas, gdy kwestionowany akt normatywny dotyczy spraw objętych zakresem ich działania (art. 191 ust. 2 w związku z art. 191 ust. 1 pkt 4 Konstytucji). Dysponują zatem tzw. legitymacją ograniczoną (zob. L. Garlicki, Komentarz do art. 191 [w:] Konstytucja Rzeczypospolitej Polskiej. Komentarz, t. V, red. L. Garlicki, Warszawa 2007, s. 7-10).

Zdaniem Trybunału: „Wniosek do Trybunału Konstytucyjnego musi być bezpośrednio związany z interesem prawnym danej organizacji jako takiej lub z interesem prawnym członków tej organizacji, do którego reprezentowania dana organizacja jest powołana. Tego rodzaju organizacje nie są natomiast legitymowane do występowania z wnioskami do Trybunału Konstytucyjnego w sprawach ogólnopaństwowych czy ogólnospołecznych, które z natury rzeczy dotyczą interesu prawnego wszystkich obywateli lub grup o wiele szerszych niż te, które dana organizacja reprezentuje" (postanowienia TK z: 24 października 1996 r., sygn. akt T 35/96; 15 lutego 2000 r., sygn. akt T 27/99). Przesłankę sformułowaną w art. 191 ust. 2 Konstytucji należy interpretować ściśle (zob. np. postanowienia TK z: 3 września 1998 r., sygn. akt U 1/98; 5 października 1999 r., sygn. akt $\mathrm{U}$ 4/99).

W doktrynie prawa wyjaśniono, że: „Punktem wyjścia oceny legitymacji danego podmiotu jest analiza przepisów prawa określających zakres jego działania. 
Nie ma znaczenia ranga tych przepisów, zawsze jest jednak konieczne wskazanie konkretnego przepisu, który zalicza daną sprawę do zakresu działania podmiotu inicjującego postępowanie" (B. Banaszak, Konstytucja Rzeczypospolitej Polskiej. Komentarz, Warszawa 2009, s. 857).

Podstawą złożenia wniosku w niniejszej sprawie była uchwała nr 3/17/VII Naczelnej Rady Lekarskiej z dnia 13 stycznia 2017 r. w sprawie wystąpienia z wnioskiem do Trybunału Konstytucyjnego. Do uchwały załączono wyciąg z protokołu z 20/VII posiedzenia NRL, na którym podjęto wspomnianą uchwałę.

Wnioskodawczyni jako źródło swojej legitymacji wskazuje art. 39 ust. 1 pkt 1 i 3 u.i.l., zgodnie z którymi NRL „sprawuje pieczę nad należytym i sumiennym wykonywaniem zawodu lekarza przez członków samorządu lekarzy” oraz „reprezentuje i chroni interesy zawodowe członków samorządu lekarzy" (wniosek, s. 7). Można też zauważyć, że NRL czuwa nad prawidłową realizacją zadań samorządu lekarzy (art. 39 ust. 1 pkt 6 u.i.l.). Do zadań samorządu lekarskiego zalicza się m.in.: przyznawanie prawa wykonywania zawodu lekarzy, prowadzenie lub udział w organizowaniu doskonalenia zawodowego lekarzy, opiniowanie i wnioskowanie w sprawach kształcenia przed-i podyplomowego lekarzy (art. 5 pkt 3 , 7, 8 u.i.l.).

Zakwestionowane we wniosku uregulowania odnoszą się do prawnych warunków uzyskania prawa do wykonywania zawodu lekarza lub lekarza dentysty oraz uzyskania tytułu specjalisty w danej dziedzinie medycyny. Uwzględniając, że wymagania określające sposób dopuszczenia do wykonywania tych zawodów lub formalnego poświadczenia kwalifikacji w zakresie specjalizacji lekarskiej lub lekarsko-dentystycznej są ściśle związane z zakresem działania wnioskodawczyni, jej legitymacja w postępowaniu przed Trybunałem Konstytucyjnym w niniejszej sprawie nie budzi wątpliwości.

3. Kolejnym zagadnieniem, na jakie należy zwrócić uwagę w analizie formalnej, jest ustalenie znaczenia wyroku TK z 7 czerwca 2016 r. (sygn. akt K 8/15) dla postępowania toczącego się $\mathrm{w}$ analizowanej sprawie. W przywołanym wyroku Trybunał stwierdził, że: „Art. 14a ust. 11 ustawy z dnia 5 grudnia 1996 r. o zawodach lekarza i lekarza dentysty (Dz. U. z 2015 r. poz. 464, 1633, 1893, 1991 i 2199 oraz z 2016 r. poz. 65), w brzmieniu nadanym przez art. 1 pkt 9 ustawy z dnia 28 kwietnia 2011 r. o zmianie ustawy o zawodach lekarza i lekarza dentysty (Dz. U. nr 113, poz. 658), w zakresie, w jakim dotyczy testów i pytań testowych z Lekarskiego Egzaminu Końcowego i Lekarsko-Dentystycznego Egzaminu Końcowego, które już się odbyły,

2) art. 16 r ust. 12 zdanie drugie ustawy z 5 grudnia 1996 r. powołanej w punkcie 1, w brzmieniu nadanym przez art. 1 pkt 13 ustawy z 28 kwietnia 2011 r. powołanej w punkcie 1, w zakresie, w jakim dotyczy zadań testowych z Państwowego Egzaminu Specjalizacyjnego, który już się odbył - są niezgodne z art. 61 ust. 3 w związku z art. 31 ust. 3 Konstytucji Rzeczypospolitej Polskiej”. Orzeczeniem tym sąd konstytucyjny zdyskwalifikował regulację, która wyłączała udostępnia- 
nie, na zasadach określonych w ustawie o dostępie do informacji publicznych testów i pytań testowych z LEK i LDEK oraz zadań testowych z PES. Trybunał Konstytucyjny, rozpoznawszy wniosek NRL, uznał wówczas, że kontrolowane przepisy ustawy o zawodzie lekarza i lekarza dentysty są niezgodne z art. 61 ust. 3 w związku z art. 31 ust. 3 Konstytucji.

Chociaż zgodnie z przedstawionymi wyżej ustaleniami problem konstytucyjny i powołany wzorzec kontroli konstytucyjności w rozpoznawanej sprawie o sygn. akt K 13/19 są takie same jak w rozstrzygniętej przez Trybunał sprawie o sygn. akt K 8/15, to nie można uznać, że wyczerpane zostały przesłanki stwierdzenia rei iudicatae, co determinowałoby konieczność umorzenia postępowania. O wystąpieniu ujemnej przesłanki procesowej w postaci powagi rzeczy osądzonej (res iudicata) można mówić tylko w przypadku tożsamości podmiotowej, przedmiotowej oraz konstytucyjnych wzorców powołanych dla kontroli zakwestionowanego przepisu (zob. postanowienie TK z 26 marca 2002 r., sygn. akt P 3/02), natomiast postępowanie $\mathrm{w}$ niniejszej sprawie dotyczy innego przepisu ustawy o zawodzie lekarza i lekarza dentysty (jakkolwiek problem ograniczenia dostępu do informacji publicznej pozostał aktualny).

W następstwie wyroku w sprawie o sygn. akt K 8/15 z systemu prawa derogowane zostały normy uniemożliwiające dostęp w trybie ustawy o dostępie do informacji publicznej do testów i pytań testowych z LEK i LDEK oraz zadań testowych z PES. Kontestowane w niniejszej sprawie przez NRL rozwiązania prawne zostały ulokowane w ustawie o zawodzie lekarza i lekarza dentysty w konsekwencji przyjęcia ustawy zmieniającej z 2016 r., która wprowadziła ograniczenie temporalne w zakresie wykorzystania w ustawie o dostępie do informacji publicznej w odniesieniu do pytań (zadań testowych) z przeprowadzonych egzaminów lekarskich oraz autonomiczny dla ustawy o zawodzie lekarza i lekarza dentysty tryb dostępu do wykorzystanych pytań (zadań) testowych.

W tej perspektywie należy wykluczyć możliwość zastosowania zasady ne bis in idem, w myśl której wydanie orzeczenia jest zbędne, jeżeli zarzut postawiony w piśmie inicjującym postępowanie przed Trybunałem Konstytucyjnym został już uprzednio rozstrzygnięty merytorycznie. W analizowanej sprawie NRL kontestuje bowiem nie wyłączenie (jak w sprawie o sygn. akt K 8/15), ale ograniczenie (przez 5 lat od dnia przeprowadzenia egzaminu lekarskiego) możliwości uzyskania informacji publicznej o pytaniach (zadaniach) testowych z przeprowadzonych egzaminów oraz dodatkowo - limitację podmiotową oraz ograniczony sposób udostępniania testów z egzaminów lekarskich.

Nie oznacza to jednak, że ustalenia Trybunału dokonane na kanwie sprawy o sygn. akt K 8/15 pozostają irrelewantne dla niniejszego postępowania. W dalszej części stanowiska nastąpi nawiązanie do poszczególnych przesłanek, na jakich oparł się Trybunał, orzekając o niekonstytucyjności kontrolowanych wówczas przepisów ustawy o zawodzie lekarza i lekarza dentysty. 


\section{Analiza merytoryczna}

\section{- Zarzuty wnioskodawczyni}

1. Naczelna Rada Lekarska formułuje swoje zastrzeżenia konstytucyjne względem norm rządzących udostępnianiem pytań wykorzystanych w LEK, LDEK oraz PES, wskazując, że pytania egzaminacyjne z przywołanych egzaminów stanowią informację publiczną, do której dostęp gwarantowany jest konstytucyjnie (art. 61 ust. 1 ustawy zasadniczej). Wnioskodawczyni wskazuje, że w orzecznictwie sądów administracyjnych przesądzono status pytań egzaminacyjnych z PES, uznając, iż stanowią one informację publiczną. Tę samą kwalifikację, zdaniem NRL, należy odnieść do pytań egzaminacyjnych z LEK i LDEK, ze względu na analogiczny tryb ich opracowywania. Dotyczy to jedynie pytań już wykorzystanych na egzaminie, a nie tych, które znajdują się w bazie pytań i nie zostały jeszcze użyte w czasie egzaminu. W przekonaniu NRL, taki status pytań pośrednio potwierdzają zakwestionowane przepisy: „To, że ustawodawca w [...] przepisach wyraźnie wyłączył na okres 5 lat udostępnianie tych pytań w trybie ustawy o dostępie do informacji publicznej oznacza, że pytania te ze swej istoty prawnej mieszczą się w pojęciu informacji publicznej" (wniosek, s. 19).

2. Naczelna Rada Lekarska podnosi, że zakwestionowana regulacja przewiduje ograniczenia w dostępie do pytań egzaminacyjnych z LEK, LDEK i PES poprzez:

a) zawężenie kręgu osób uprawnionych do uzyskania informacji o pytaniach wyłącznie do osób, które przystępują do danego egzaminu,

b) umożliwienie dostępu do pytań tylko w siedzibie Centrum Egzaminów Medycznych,

c) limitowanie dostępu do pytań przez ich okazanie, bez możliwości ich reprodukowania, kopiowania jakąkolwiek techniką lub przepisywania,

d) umożliwienie dostępu do pytań w trybie ustawy o dostępie do informacji publicznej dopiero po upływie 5 lat od dnia przeprowadzenia danego egzaminu.

Ograniczenie dostępności informacji publicznej jest dopuszczalne tylko wówczas, gdy jest zgodne z art. 61 ust. 3 w związku z art. 31 ust. 3 Konstytucji. Jak zauważa NRL, w uzasadnieniu projektu ustawy zmieniającej z 2016 r. nie wyjaśniono, z jakiego względu projektodawca uznaje za niezbędne ograniczenie dostępu do zadań z PES, LEK i LDEK, bowiem w pierwotnym tekście projektu ustawy zmieniającej z 2016 r. (druk sejmowy nr 769/VIII kad.) nie zostały pomieszczone przepisy będące przedmiotem wątpliwości konstytucyjnych wnioskodawczyni. Rekonstruując ratio legis kwestionowanej regulacji z wypowiedzi przedstawicieli projektodawcy w trakcie prac legislacyjnych, NRL wskazuje, że „w toku prac parlamentarnych nad projektem ustawy brak było wyraźnego odniesienia się do którejś z przesłanek z art. 61 ust. 3 Konstytucji. Razi to szczególnie w sytuacji, kiedy wprowadzenie tego rodzaju ograniczenia było "reakcją» ustawodawcy na przegranie sprawy w Trybunale Konstytucyjnych [sprawy o sygn. akt K 8/15 uwaga K.M.-D.]" (wniosek, s. 27-28). 
W opinii NRL za ograniczeniem prawa dostępu do wykorzystanych pytań egzaminacyjnych z PES, LEK i LDEK nie przemawiają żadne z wartości wymienionych w art. 61 ust. 3 Konstytucji.

Ograniczenia tego nie usprawiedliwia argument, że LEK i LDEK składają się z 200 pytań i w razie ich ujawnienia w krótkim czasie wyczerpałyby się zasoby wiedzy, z których można ułożyć nowe zadania. Jak bowiem wskazuje wnioskodawczyni, zakres wiedzy wymaganej na tych egzaminach jest bardzo szeroki i obejmuje niemal prawie cały program studiów medycznych. W przypadku PES należy dodatkowo wziąć pod uwagę, że składa się on także z części ustnej (wniosek, s. 33-34).

Wnioskodawczyni jednoznacznie dyskwalifikuje argument, zgodnie z którym ujawnienie wykorzystanych pytań egzaminacyjnych spowoduje, że osoby przystępujące do egzaminu będą się uczyć rozwiązywania testów zamiast zdobywać niezbędną wiedzę z zakresu medycyny. Jak bowiem wiadomo: „Istnieje powszechny dostęp do pytań z szeregu niezwykle ważnych egzaminów przeprowadzanych pod auspicjami państwa. [...] Nie jest tajemnicą, że w czasie każdego egzaminu liczy się zarówno zdobyta wiedza jak też umiejętność radzenia sobie z określonym sposobem i techniką zadawania pytań" (wniosek, s. 36). Gdy zaś chodzi o PES, przyjęty system szkolenia specjalizacyjnego - zakładający zdobywanie nie tylko wiedzy teoretycznej, ale także praktycznych umiejętności pod nadzorem lekarza ze specjalizacją - wyklucza możliwość dopuszczenia do egzaminu osób, które potrafią jedynie rozwiązywać testy egzaminacyjne. $Z$ tych względów nie sposób zasadnie twierdzić, że udostępnienie testów skutkowałoby obniżeniem poziomu kształcenia i w konsekwencji zagrożeniem dla bezpieczeństwa pacjentów.

Negatywnie NRL ocenia także argument, w myśl którego społeczna kontrola pytań egzaminacyjnych nie jest potrzebna, gdyż pytania te są opracowywane przez autorytety medyczne, w tym m.in. przez konsultantów z poszczególnych dziedzin medycyny. Niewątpliwie stanowi to gwarancję wysokiego poziomu merytorycznego pytań, jednak ujawnienie testów z lat ubiegłych mogłoby posłużyć weryfikacji, czy zakres wymaganej wiedzy znajduje pokrycie w podręcznikach wykorzystywanych na studiach medycznych, a także ukierunkowaniu osób przystępujących do danego egzaminu na zagadnienia często pojawiające się na egzaminie i sprawiające zdającym trudność.

Wnioskodawczyni twierdzi ponadto, że „przyznanie prawa dostępu do tych pytań [z egzaminów lekarskich - uwaga K.M.-D.] dopiero po 5 latach od daty egzaminu nie daje szans na rzeczywisty społeczny nadzór nad wykonywaniem zadań należących do władzy publicznej [...] jest to stwarzanie jedynie pozoru zapewnienia kontroli” (wniosek, s. 35).

\section{- Wzorce kontroli}

1. Podstawowym wzorcem kontroli wnioskodawczyni uczyniła art. 61 ust. 3 Konstytucji w brzmieniu: „Ograniczenie prawa, o którym mowa w ust. 1 i 2, może 
nastąpić wyłącznie ze względu na określone w ustawach ochronę wolności i praw innych osób i podmiotów gospodarczych oraz ochronę porządku publicznego, bezpieczeństwa lub ważnego interesu gospodarczego państwa”.

Prawo zakotwiczone w art. 61 ust. 1 i ust. 2 Konstytucji, to prawo do informacji publicznej. Zgodnie ze wspomnianymi przepisami: „Obywatel ma prawo do uzyskiwania informacji o działalności organów władzy publicznej oraz osób pełniących funkcje publiczne. Prawo to obejmuje również uzyskiwanie informacji o działalności organów samorządu gospodarczego i zawodowego, a także innych osób oraz jednostek organizacyjnych w zakresie, w jakim wykonują one zadania władzy publicznej i gospodarują mieniem komunalnym lub majątkiem Skarbu Państwa” (art. 61 ust. 1 Konstytucji); „Prawo do uzyskiwania informacji obejmuje dostęp do dokumentów oraz wstęp na posiedzenia kolegialnych organów władzy publicznej pochodzących z powszechnych wyborów, z możliwością rejestracji dźwięku lub obrazu” (art. 61 ust. 2 Konstytucji).

Jak wskazywał Trybunał Konstytucyjny: „Powszechny i szeroki dostęp do informacji publicznej stanowi niezbędną przesłankę istnienia społeczeństwa obywatelskiego, a co za tym idzie - urzeczywistnienia demokratycznych zasad funkcjonowania władzy publicznej w polskim państwie prawnym. Dostęp do informacji publicznej jest bowiem [...] warunkiem świadomego uczestnictwa obywateli w podejmowaniu rozstrzygnięć władczych [...]. Stąd wielkie znaczenie powszechności dostępu do informacji publicznej. W demokratycznym społeczeństwie podstawowym prawem jest wiedzieć i być informowanym o tym, co i dlaczego czynią władze publiczne [...] Ustrojowa doniosłość dostępności do informacji publicznej dla obywateli uzasadnia umieszczenie w Konstytucji ochrony prawa obywateli do uzyskania takiej informacji” (wyrok TK z 15 października 2009 r., sygn. akt K 26/08). Ratio legis art. 61 ust. 1 Konstytucji jest możliwość sprawowania kontroli społecznej organów władzy publicznej. Pogląd taki wyraził Naczelny Sąd Administracyjny w Warszawie, który w wyroku z 31 maja 2004 r. (sygn. akt OSK 205/04) orzekł, że uzasadnienie tej regulacji „wynika z zasady udziału obywateli w życiu publicznym i sprawowania społecznej kontroli. W celu zaś realizacji tej zasady obywatel ma prawo uzyskania wiedzy o sprawach publicznych".

2. W art. 61 ust. 3 Konstytucji wskazano, że ograniczenie prawa do informacji publicznej musi mieć podstawę ustawową i może nastąpić wyłącznie ze względu na wymienione $\mathrm{w}$ tym przepisie wartości. Takie ujęcie nakazuje ustalić relację między art. 61 ust. 3 Konstytucji a ogólną klauzulą limitacyjną zawartą w art. 31 ust. 3 Konstytucji, zgodnie z którym: „Ograniczenia w zakresie korzystania z konstytucyjnych wolności i praw mogą być ustanawiane tylko w ustawie i tylko wtedy, gdy są konieczne w demokratycznym państwie dla jego bezpieczeństwa lub porządku publicznego, bądź dla ochrony środowiska, zdrowia i moralności publicznej, albo wolności i praw innych osób. Ograniczenia te nie mogą naruszać istoty wolności i praw". 
Trybunał Konstytucyjny odniósł się następująco do tego zagadnienia w wyroku z 20 marca 2006 r. (sygn. akt K 17/05): „Art. 31 ust. 3 jest [...] modyfikowany przez art. 61 ust. 3 Konstytucji jedynie w zakresie, w którym regulowane są (węziej) bezpośrednio przesłanki ingerencji, natomiast w pełni pozostaje aktualne zastosowanie pozostałych elementów proporcjonalności niewyrażonych w art. 61 ust. 3 (w szczególności konieczność uwarunkowana standardem demokratycznego państwa oraz zakaz ingerowania w istotę prawa). Wspólną dla obu konstrukcji przesłanką uzasadniającą ograniczenia jest też konieczność ochrony praw i wolności innych osób”.

Pogląd ten został rozwinięty w późniejszym orzecznictwie trybunalskim: „Wzajemny stosunek obu wskazanych norm konstytucyjnych nie rysuje się jednoznacznie. Możliwy jest teoretycznie pogląd, że art. 61 ust. 3 stanowi regulację szczególną (lex specialis) w stosunku do ogólnej zasady wyrażonej w art. 31 ust. 3 Konstytucji. Oznaczałoby to nie tylko zawężenie samych przesłanek ingerencji (warto zauważyć, że art. 61 ust. 3 nie wskazuje na moralność publiczną, ochronę środowiska oraz zdrowie publiczne jako na wartości uzasadniające ingerencję ustawodawczą), ale wywoływałoby konsekwencje znacznie dalej idące. Odnosiłyby się one bowiem do samego mechanizmu proporcjonalności i jego konstrukcji, która opiera się na założeniu ważenia pozostających w konflikcie dóbr, wyraźnego zakreślenia granic niezbędności wkroczenia w sferę gwarantowanego prawa oraz zakresu zakazu takiego wkroczenia. Art. 31 ust. 3 Konstytucji wymaga uzasadnienia ingerencji zawsze wtedy, kiedy jest to «konieczne w demokratycznym państwie», a ponadto bezwzględnie zakazuje wkraczania w istotę gwarantowanego prawa. Trybunał Konstytucyjny przychyla się do stanowiska, prezentowanego już wcześniej w orzecznictwie, że nawet jeśli norma szczegółowa Konstytucji wyznacza samodzielnie przesłanki ingerencji w sferze prawa, tak jak to czyni art. 61 ust. 3 w odniesieniu do prawa do informacji o działalności instytucji publicznych, nie może to oznaczać eliminacji pozostałych elementów mechanizmu proporcjonalności z art. 31 ust. 3 Konstytucji. Przepisy te mają w stosunku do siebie charakter komplementarny" (wyrok TK z 15 października 2009 r., sygn. akt K 26/08).

Aktualność powyższego stanowiska uzyskała w ostatnim czasie potwierdzenie: „Zgodnie z dotychczasowym orzecznictwem Trybunału, art. 31 ust. 3 Konstytucji jest modyfikowany przez art. 61 ust. 3 Konstytucji jedynie w zakresie, w którym regulowane są w sposób odrębny przesłanki ingerencji, natomiast w pełni pozostaje aktualne zastosowanie pozostałych elementów niewyrażonych w art. 61 ust. 3 Konstytucji. W szczególności chodzi tu o warunek, aby ograniczenie było konieczne w demokratycznym państwie prawnym, a także o proporcjonalność ograniczeń oraz o zakaz naruszania istoty prawa" (wyrok TK z 9 kwietnia 2015 r., sygn. akt K 14/13; por. też M. Bernaczyk, Prawo do informacji publicznej w Polsce i na świecie, Warszawa 2014, s. 317-318).

Jak podkreślił Trybunał w wyroku z 7 czerwca 2016 r. (sygn. akt K 8/15), „niedopuszczalne jest więc ograniczenie prawa do informacji, gdy jest to konieczne 
dla ochrony środowiska, zdrowia i moralności publicznej, natomiast jest dopuszczalne - czego nie przewiduje art. 31 ust. 3 Konstytucji - dla ochrony ważnego interesu gospodarczego państwa. Ponadto gdy wśród przesłanek ogólnych (art. 31 ust. 3) wymienia się tylko wzgląd na wolności i prawa innych osób, to przesłanki szczególne (art. 61 ust. 3) obejmują także wolności i prawa podmiotów gospodarczych, podkreślając dodatkowo szeroki zakres podmiotowy beneficjentów ustawowo chronionych wolności i praw".

W konsekwencji ograniczenie konstytucyjnego prawa dostępu do informacji publicznej wymaga łącznego spełnienia warunków, do których należą: a) ustawowa forma ograniczenia; b) istnienie w państwie demokratycznym konieczności wprowadzenia ograniczenia (zasada proporcjonalności); c) funkcjonalny związek ograniczenia z realizacją choć jednej wartości spośród wskazanych w art. 61 ust. 3 Konstytucji (ochrona wolności i praw innych osób i podmiotów gospodarczych, ochrona porządku publicznego, bezpieczeństwa lub ważnego interesu gospodarczego państwa); d) zakaz naruszania istoty danego prawa lub wolności.

Uzupełniająco można przypomnieć, że zasada proporcjonalności, wskazana powyżej $w$ pkt b, jest $w$ orzecznictwie Trybunału rozumiana jako suma trzech zasad składowych: a) zasady przydatności - wymagającej ustalenia, czy według dostępnego stanu wiedzy wprowadzona regulacja jest w stanie doprowadzić do zamierzonych skutków (test racjonalności instrumentalnej); b) zasady konieczności - wymagającej oceny, czy badane przepisy są niezbędne dla ochrony wartości konstytucyjnych oraz czy spośród środków skutecznie chroniących te wartości zostały wybrane środki najmniej uciążliwe; c) zasady proporcjonalności sensu stricto - nakazującej ustalenie, czy efekty zaskarżonej regulacji pozostają w odpowiedniej proporcji do ciężarów nakładanych przez nią na jednostkę (np. wyrok TK z 11 kwietnia 2000 r., sygn. akt K 15/98).

\section{- Analiza zgodności}

1. Odpowiedź na zgłoszone przez NRL zarzuty niekonstytucyjności, dla porządku prowadzonego wywodu, musi zostać poprzedzona rekonstrukcją ramowych zasad organizacji i przeprowadzania egzaminów lekarskich.

Zarówno LEK, jak i LDEK są organizowane i przeprowadzane przez Centrum Egzaminów Medycznych (dalej: Centrum, CEM), będące państwową jednostką budżetową podległą ministrowi właściwemu do spraw zdrowia (art. 14a ust. 1 u.z.l.). Odbywają się równocześnie, dwa razy do roku (art. 14a ust. 2 u.z.l.). Egzaminy te są składane w formie testów pisemnych - odrębnych dla zawodu lekarza i zawodu lekarza dentysty - opracowanych na każdy termin egzaminu przez ekspertów w zakresie zagadnień objętych LEK i LDEK (art. 14c ust. 1 u.z.l.). Obejmują problematykę z zakresu dziedzin medycyny, ze szczególnym uwzględnieniem procedur diagnostycznych i leczniczych (art. 14c ust. 2 u.z.l.). Test składa się z 200 pytań zawierających pięć odpowiedzi, z których tylko jedna jest prawidłowa; za każdą prawidłową odpowiedź uzyskuje się 1 punkt (art. 14d ust. 2 u.z.l.). 
Testy i pytania testowe LEK i LDEK są opracowywane, przetwarzane, dystrybuowane i przechowywane w sposób uniemożliwiający dostęp do nich osobom innym niż uczestniczące w ich opracowywaniu, przetwarzaniu, dystrybuowaniu i przechowywaniu, przeprowadzającym LEK lub LDEK lub sprawującym nadzór nad ich przeprowadzeniem (art. 14c ust. 3 u.z.l.).

Zgodnie z $\$ 2$ ust. 2 rozporządzenia Ministra Zdrowia z dnia 21 października 2017 r. w sprawie Lekarskiego Egzaminu Końcowego i Lekarsko-Dentystycznego Egzaminu Końcowego (Dz. U. poz. 1877), LEK zawiera pytania z następującego zakresu: 1) chorób wewnętrznych, w tym chorób układu sercowo-naczyniowego - 39 pytań; 2) pediatrii, w tym neonatologii - 29 pytań; 3) chirurgii, w tym chirurgii urazowej - 27 pytań; 4) położnictwa i ginekologii - 26 pytań; 5) psychiatrii - 14 pytań; 6) medycyny rodzinnej - 20 pytań; 7) medycyny ratunkowej i intensywnej terapii - 20 pytań; 8) bioetyki i prawa medycznego - 10 pytań; 9) orzecznictwa lekarskiego - 7 pytań; 10) zdrowia publicznego - 8 pytań, przy czym wśród pytań z zakresu chorób wewnętrznych, pediatrii, chirurgii, położnictwa i ginekologii oraz medycyny rodzinnej znajduje się co najmniej 20 pytań z dziedziny onkologii.

Zakres LDEK obejmuje natomiast zagadnienia: 1) stomatologii zachowawczej - 46 pytań, 2) stomatologii dziecięcej - 29 pytań, 3) chirurgii stomatologicznej - 25 pytań, 4) protetyki stomatologicznej - 25 pytań, 5) periodontologii - 20 pytań, 6) ortodoncji - 20 pytań, 7) medycyny ratunkowej - 10 pytań, 8) bioetyki i prawa medycznego - 10 pytań, 9) orzecznictwa lekarskiego - 7 pytań, 10) zdrowia publicznego - 8 pytań, przy czym wśród pytań z zakresu stomatologii zachowawczej, stomatologii dziecięcej, chirurgii stomatologicznej, periodontologii i ortodoncji znajduje się co najmniej 20 pytań z dziedziny onkologii ( $\$ 2$ ust. 2 przywołanego wyżej rozporządzenia).

Pozytywny wynik z LEK albo LDEK otrzymuje zdający, który uzyskał co najmniej 56\% maksymalnej liczby punktów z testu (art. 14e ust. 4 zdanie pierwsze u.z.l.).

Państwowy Egzamin Specjalizacyjny jest organizowany również dwa razy do roku przez CEM (art. 16rc ust. 1 u.z.l.). Dla każdej specjalności jest on składany $\mathrm{w}$ formie egzaminu testowego i egzaminu ustnego, w kolejności ustalonej przez dyrektora Centrum, obejmujących zakres odbytego szkolenia specjalizacyjnego, ze szczególnym uwzględnieniem procedur diagnostycznych i leczniczych, z wyłączeniem wykonywania inwazyjnych zabiegów i procedur medycznych (art. 16rc ust. 2 u.z.l.), przy czym w uzasadnionych przypadkach minister właściwy do spraw zdrowia może, na wniosek dyrektora Centrum, wyrazić zgodę m.in. na odstąpienie od przeprowadzenia egzaminu testowego PES dla wszystkich lekarzy dopuszczonych do PES w danej dziedzinie w określonej sesji egzaminacyjnej, z zachowaniem egzaminu ustnego (art. 16rc ust. 3 u.z.l.). Testy i pytania testowe opracowuje i ustala Centrum w porozumieniu z konsultantem krajowym właściwym dla danej dziedziny medycyny lub jego przedstawicielem odrębnie dla każdej dziedziny medycyny oraz na każdą sesję egzaminacyjną (art. 16rc ust. 4 
u.z.l.). Analogicznie do zasady dedykowanej LEK i LDEK testy, pytania i zadania egzaminacyjne na PES są opracowywane, przetwarzane, dystrybuowane i przechowywane w sposób uniemożliwiający dostęp do nich przez osoby inne niż uczestniczące w ich opracowywaniu, przetwarzaniu, dystrybuowaniu i przechowywaniu, przeprowadzające PES lub sprawujące nadzór nad ich prowadzeniem (art. 16rc ust. 5 u.z.l.). Egzamin testowy wchodzący w skład PES polega na rozwiązaniu 120 pytań zawierających pięć wariantów odpowiedzi, z których tylko jeden jest prawidłowy, punktowanych tak samo jak w przypadku LEK i LDEK (art. 16 s ust. 3 u.z.1.). Część testową PES uważa się za zaliczoną z wynikiem pozytywnym po uzyskaniu przez lekarza co najmniej 60\% maksymalnej liczby punktów (art. 16s ust. 4 u.z.l.). Wykaz specjalizacji lekarskich i lekarsko-dentystycznych determinujących zakres szkolenia specjalizacyjnego i merytoryczny zakres PES, a także szczegółowy sposób i tryb składania PES oraz ustalania jego wyników zostały uregulowane w rozporządzeniu Ministra Zdrowia z 29 marca 2019 r. w sprawie specjalizacji lekarzy i lekarzy dentystów (Dz. U. poz. 602).

2. Przystępując do oceny zgodności z Konstytucją zakwestionowanych przepisów, warto na wstępie wyjaśnić, że status materiałów egzaminacyjnych wykorzystywanych w ramach LEK, LDEK i PES pozostaje poza sporem. Petryfikując w tym zakresie ustalenia sądów administracyjnych (por. w szczególności wyroki: WSA w Łodzi z 20 grudnia 2010 r., sygn. akt II SAB/Łd 53/10; NSA z 21 lipca 2011 r., sygn. akt I OSK 678/11; WSA w Łodzi z 24 sierpnia 2011 r., sygn. akt II SAB/Łd 23/11; NSA z 14 marca 2012 r., sygn. akt I OSK 2443/11), Trybunał w uzasadnieniu wyroku w sprawie o sygn. akt K 8/15 uznał, że: „Zadania testowe użyte w trakcie PES są dokumentem urzędowym [o którym mowa w art. 61 ust. 2 Konstytucji - uwaga K.M.-D.] zawierającym w sobie informacje wykorzystywane przez organ, służące realizacji jego zadań, a więc stanowiące informację publiczną, zaś Dyrektor CEM jest podmiotem zobowiązanym do udzielenia informacji publicznej [...] powyższe stanowisko należy odnieść także do testów i pytań testowych do LEK i LDEK".

3. Przyjmując, w ślad za przywołanymi ustaleniami judykatury, że wykorzystane materiały egzaminacyjne stanowią informację publiczną, która wolą ustawodawcy nie podlega udostępnieniu, należy rozważyć kwestię dopuszczalności ograniczenia prawa do informacji publicznej. Jak wynika z uzasadnienia wniosku, zasadniczym przedmiotem wątpliwości konstytucyjnych NRL jest brak związku ograniczenia tego prawa z wartościami wskazanymi w art. 61 ust. 3 Konstytucji.

Należy w tym miejscu przypomnieć, że wnioskodawczyni upatruje limitującej funkcji zaskarżonych przepisów w tym, że: wyłączają dostęp do pytań testowych wykorzystanych w egzaminach lekarskich w trybie ustawy o dostępie do informacji publicznej przez okres 5 lat od dnia przeprowadzenia egzaminu (art. 14c ust. 5 oraz art. 16rc ust. 7 u.z.l.), ograniczają - w relacji do standardu konstytucyjnego z art. 61 ust. 1 ustawy zasadniczej gwarantującego dostęp do informacji publicznej każdemu obywatelowi - krąg podmiotów uprawnionych do 
pozyskania pytań (zadań) testowych z LEK, LDEK i PES, wskazując jako uprawnioną „osobę przystępującą do egzaminu” (art. 14c ust. 4 oraz art. 16rc ust. 6 u.z.l.) oraz formę udostępnienia informacji publicznej - przez możliwość jedynie wglądu do przeprowadzonych zadań testowych, w siedzibie CEM, bez możliwości ich utrwalania. Nie ulega wątpliwości, iż kontestowane przez NRL regulacje stanowią ograniczenie w dostępie do informacji publicznej.

Zważywszy, że art. 61 ust. 3 Konstytucji dezaktualizuje dopuszczalne według art. 31 ust. 3 Konstytucji cele ograniczeń, przez modyfikację zawartego tam wyliczenia wartości chronionych, ocena konstytucyjności zakwestionowanych przepisów wymaga ustalenia, czy ograniczenie prawa do informacji uzasadniała konieczność ochrony jednej z wartości wymienionych w art. 61 ust. 3 Konstytucji - wolności i praw innych osób i podmiotów gospodarczych, porządku publicznego, bezpieczeństwa lub ważnego interesu gospodarczego państwa.

4. Wnioskodawczyni nie argumentuje odrzucenia przezeń możliwości uzasadnienia kwestionowanego ograniczenia w świetle poszczególnych wartości wymienionych w art. 61 ust. 3 Konstytucji. Formułuje natomiast twierdzenie o braku związku z którąkolwiek z nich, dodając: „Podstawowym zarzutem wobec zaskarżonych przepisów ustawy o zawodach lekarza i lekarza dentysty jest to, że ograniczenie prawa dostępu do informacji publicznej zostało dokonane, mimo że nie przemawiają za tym ograniczeniem żadne $\mathrm{z}$ wartości wymienione w art. 61 ust. 3 Konstytucji. W pełni zasadne - i podzielane przez wnioskodawcę - są tutaj rozważania Trybunału Konstytucyjnego zawarte w uzasadnieniu wyroku z dnia 7 czerwca 2016 r. [...] publiczny, jawny dostęp do testów nie narusza wolności i praw innych osób i podmiotów gospodarczych, nie zagraża porządkowi publicznemu, bezpieczeństwu lub ważnemu interesowi gospodarczemu państwa” (wniosek, s. 30). W dalszej części wywodu NRL polemizuje $\mathrm{z}$ twierdzeniami powoływanymi w toku prac parlamentarnych zmierzających do przyjęcia kwestionowanych przez nią przepisów. Wobec powyższego Sejm jest skłonny uznać, że przedstawiona przez wnioskodawczynię argumentacja spełnia warunki formalne wymagane do zainicjowania postępowania przed sądem konstytucyjnym. Jednocześnie jednak należy zastrzec, że podnoszony przez NRL brak wykazania konstytucyjnej przesłanki ograniczenia prawa do informacji publicznej w uzasadnieniu projektu ustawy zmieniającej z 2016 r., która wprowadziła sporne regulacje, nie uzasadnia odstąpienia przez wnioskodawczynię od konfrontacji zaskarżonych przepisów z poszczególnymi przesłankami zawartymi w art. 61 ust. 3 Konstytucji, a już z pewnością nie przesądza o niespełnieniu żadnej z nich. Szczegółowość uzasadnienia projektu ustawy, zwłaszcza w przypadku aktów o znacznej obszerności, jest pozostawiona uznaniu ustawodawcy, a spełnienie wymagań formalnych w tym zakresie jest na początku procesu legislacyjnego weryfikowane przez Marszałka Sejmu (zob. art. 34 ust. 7 uchwały Sejmu Rzeczypospolitej Polskiej z 30 lipca 1992 r. - Regulamin Sejmu Rzeczypospolitej Polskiej; t.j. M.P. 2012, poz. 32, ze zm.). 
5. Argumenty przywoływane - i konsekwentnie odrzucane - w toku wywodu wnioskodawczyni odnoszą się, najogólniej rzecz biorąc, do następujących zagadnień: a) możliwego wyczerpania się zasobów wiedzy, z których można układać pytania i zadania testowe; b) obniżenia się poziomu kształcenia lekarzy w wyniku nadmiernej koncentracji na rozwiązywaniu testów, tj. uczenia się „do egzaminu" zamiast zdobywania wiedzy medycznej; c) zbędności kontroli społecznej nad egzaminami lekarskimi, co ma wynikać $\mathrm{z}$ autorytetu naukowego osób układających pytania.

Zdaniem Sejmu dwa pierwsze argumenty mogą zostać uznane za wykazujące związek z ochroną porządku publicznego w rozumieniu art. 61 ust. 3 Konstytucji. Pojęcie porządku publicznego jest dekodowane w orzecznictwie Trybunału Konstytucyjnego szeroko, ze wskazaniem, że chodzi o takie ukształtowanie stanu faktycznego wewnątrz państwa, które umożliwia normalne współżycie jednostek w organizacji państwowej (zob. wyroki TK z: 12 stycznia 1999 r., sygn. akt P 2/98; 4 listopada 2014 r., sygn. akt SK 55/13). Zagrożenia godzące w harmonijną i sprawną organizację życia publicznego należy przy tym oceniać właśnie pod kątem ochrony porządku publicznego, podczas gdy zagrożenia dla podstaw bytu państwa, integralności jego terytorium, losu jego mieszkańców lub istoty systemu rządów winny być postrzegane z perspektywy ochrony bezpieczeństwa państwa (zob. np. wyrok TK z 6 lipca 2011 r., sygn. akt P 12/09, i cytowane tam orzecznictwo). W badanej sprawie przez porządek publiczny należy rozumieć taką organizację egzaminów medycznych, która umożliwia sprawne, rzetelne i miarodajne potwierdzanie przez państwo kwalifikacji osób wykonujących zawody lekarza i lekarza dentysty, zaliczane wszakże do zawodów zaufania publicznego.

Można ponadto podjąć próbę uzasadnienia ograniczenia dostępu do informacji publicznej w perspektywie prawa do ochrony zdrowia (jako prawa innych osób, wskazanego w art. 61 ust. 3 ustawy zasadniczej), zakotwiczonego w art. 68 ust. 1 Konstytucji. Prawo to inkorporuje możliwość korzystania z systemu ochrony zdrowia, funkcjonalnie ukierunkowanego na zwalczanie i zapobieganie chorobom, urazom i niepełnosprawności (wyrok TK z 23 marca 1999 r., sygn. akt K 2/98).

W tradycyjnym rozumieniu organizacja systemu ochrony zdrowia utożsamiana jest $\mathrm{z}$ takimi działaniami państwa, jak świadczenia zdrowotne, system zabezpieczeń społecznych, refundacja leków czy system lecznictwa zamkniętego lub organizacja obowiązkowych szczepień. Podkreślić należy jednak, że regulację kwalifikacji zawodowych osób dopuszczanych do wykonywania zawodów medycznych można także klasyfikować jako działanie państwa zmierzające do optymalizacji systemu ochrony zdrowia.

Trzeci argument podnoszony we wniosku należy natomiast uznać za irrelewantny z punktu widzenia art. 61 ust. 3 Konstytucji, a ponadto nietrafny. $\mathrm{W}$ demokratycznym państwie prawnym gospodarowanie środkami publicznymi, związane z realizacją przez państwo zadań publicznych, nie może być wyję- 
te spod kontroli społecznej (wyrok TK z 7 stycznia 2004 r., sygn. akt K 14/03), nawet jeżeli przemawiają za tym szczególnie wysokie kwalifikacje intelektualne i etyczne osób odpowiedzialnych za realizację owych zadań.

6. Zdaniem Sejmu, jakkolwiek kwestionowane ograniczenie wykazuje związek z ochroną porządku publicznego i prawem do ochrony zdrowia, należy podzielić wątpliwości NRL, która wskazuje, że nie jest ono w stanie doprowadzić do realizacji zakładanego celu, tj. nie służy organizacji egzaminów medycznych w sposób wyżej opisany.

Argument odnoszący się do możliwego wyczerpania się zasobów wiedzy (tzw. puli pytań) nie może stanowić uzasadnienia dla nieudostępniania testów i pytań (zadań) testowych $\mathrm{z}$ egzaminów lekarskich w trybie przewidzianym dla informacji publicznej. Jak słusznie podnosi NRL, jest on bezzasadny, jeżeli weźmie się pod uwagę, że egzaminy te obejmują w zasadzie całość wiedzy ze studiów medycznych (LEK, LDEK) lub kształcenia specjalizacyjnego (PES). Jest to materiał bez porównania szerszy niż chociażby w przypadku egzaminów gimnazjalnego i maturalnego, które nie zostały objęte przez ustawodawcę analogicznym reżimem. Warto w tym kontekście zwrócić uwagę na to, że niezwykle dynamiczny rozwój nauk medycznych i postępy medycyny wpływają na ewolucję potencjalnego materiału egzaminacyjnego, który determinuje zakres pytań lub prawidłowych na nie odpowiedzi.

W nauce prawa zwraca się też uwagę, że analogicznego do kwestionowanego przez NRL ograniczenia nie zawierają przepisy ustaw regulujących status pytań testowych, które zostały użyte w poprzednich egzaminach adwokackich, radcowskich czy notarialnych (W. Preiss [w:] Ustawa o zawodach lekarza i lekarza dentysty. Komentarz, red. E. Zielińska, Warszawa 2014, s. 283). Przywoływany jest także przykład egzaminów wstępnych na aplikacje prawnicze (zob. wystąpienie Rzecznika Praw Obywatelskich do Ministra Zdrowia z 29 października 2013 r., nr RPO-747976-V/13/AA, s. 5). W żadnym z tych wypadków proces egzaminacyjny nie został sparaliżowany z powodu jawności wykorzystanych materiałów. Jak zauważył Trybunał: „Ten w istocie pozaprawny argument nie wytrzymuje konfrontacji z przesłankami ograniczenia prawa do informacji, sformułowanymi w art. 61 ust. 3 Konstytucji” (wyrok z 7 czerwca 2016 r., sygn. akt K 8/15). Na istotny argument w tym zakresie zwrócił również Prokurator Generalny w sprawie o sygn. akt K 8/15, wskazując, iż możliwości sprawdzenia kwalifikacji lekarskich są szerokie i nie ograniczają się wyłącznie do wykorzystania w tym celu testów. Pogląd ten zaaprobował Trybunał, uznając, że jeżeli „jednak ustawodawca uznał, że ta forma jest najwygodniejsza, to zadaniem CEM jest przygotowanie testów, które wymuszają na osobach składających egzamin opanowanie materiału niezbędnego do wykonywania zawodu lekarza lub pełnienia obowiązków specjalisty".

Nawet gdyby jednak przyjąć, że liczba możliwych (wartościowych egzaminacyjnie) pytań i zadań testowych jest skończona i że w związku z tym muszą 
się one co pewien czas - w mniej lub bardziej zmienionej formie redakcyjnej powtarzać, to trudno nie zauważyć, że obecny sposób organizacji egzaminów lekarskich nie sprzyja utrzymaniu w tajemnicy treści wykorzystanych materiałów. Osoby przystępujące do egzaminów nie są bowiem prawnie zobowiązane do zachowania poufności co do zawartości arkuszy egzaminacyjnych, zapamiętanej $\mathrm{w}$ trakcie egzaminu lub w związku z dostępem na podstawie art. 14c ust. 4 u.z.l. W konsekwencji upowszechniają się prywatne zbiory pytań, szeroko dostępne m.in. w zasobach internetowych, bazujące na pytaniach zapamiętanych i spisanych - nie zawsze dokładnie - przez osoby, które już przystępowały do egzaminu. Potencjalne nieścisłości w tych zbiorach z pewnością nie są korzystne z punktu widzenia procesu kształcenia i samokształcenia lekarzy.

Sejm podziela pogląd wnioskodawczyni, że przyjęcie ograniczenia kręgu podmiotów uprawnionych do pozyskania informacji o treści pytań (zadań) testowych podczas egzaminów lekarskich w okresie do 5 lat od przeprowadzenia egzaminu niweczy w praktyce możliwość społecznej kontroli nad wykonywaniem obowiązków publicznych przez CEM (wniosek, s. 34-35), a takie ratio przyświecało przyjęciu art. 61 ust. 1 Konstytucji.

$\mathrm{Na}$ uwzględnienie nie zasługuje też argument wskazujący na potrzebę ograniczania zjawiska uczenia się „do egzaminu” - rozumianego jako nadmierna koncentracja na strategiach egzaminacyjnych kosztem pogłębiania wiedzy na temat samych zagadnień objętych zadaniami i pytaniami. Sejm podziela pogląd wnioskodawczyni, która stwierdza, że „przyjęty system szkolenia specjalizacyjnego i model egzaminowania przewidujący także część ustną wyklucza możliwość zdania egzaminu [PES - uwaga K.M.-D.] przez osoby, które nie potrafią nic innego poza rozwiązywaniem testów egzaminacyjnych" (wniosek, s. 32); NRL odrzuca ponadto „sprowadzenie wiedzy wymaganej od kandydata na egzaminie LEK i LDEK do opanowania odpowiedzi na pytania egzaminacyjne $z$ lat ubiegłych” (wniosek, s. 32). Znaczenie ma tu zarówno obszerność materiału objętego egzaminami, jak i wieloetapowość procedury uzyskiwania kwalifikacji do wykonywania zawodów medycznych (zwłaszcza egzamin ustny w przypadku PES). Odnosząca się do powyższych kwestii opinia organu samorządu lekarskiego, z mocy prawa dokonującego czynności związanych z decydowaniem lub współdecydowaniem o dopuszczeniu do wykonywania zawodu zaufania publicznego, powinna być potraktowana ze szczególną uwagą.

Nie należy też tracić z pola widzenia, że sama znajomość standardu trudności i sposobu formułowania pytań egzaminacyjnych nie stanowi zagrożenia dla sprawnej organizacji egzaminów medycznych, a wręcz przeciwnie - sprzyja rzetelnemu przygotowaniu się do procedury weryfikacji kwalifikacji zawodowych i lepszemu rozeznaniu co do zakresu wymaganej wiedzy.

7. W konsekwencji zaskarżone przepisy, nawet gdyby uznać, że przyjęte zostały z uwzględnieniem przesłanek zakotwiczonych w art. 61 ust. 3 Konstytucji, nie spełniają zasady przydatności ograniczenia (testu racjonalności instru- 
mentalnej) do ochrony porządku publicznego czy praw innych osób (prawa do ochrony zdrowia). Sprawia to, że zbędna staje się ich ocena według pozostałych elementów testu proporcjonalności (zasady konieczności, zasady proporcjonalności sensu stricto). Analizowane ograniczenie prawa do informacji publicznej nie może zatem zostać uznane za dopuszczalne konstytucyjnie.

Sejm ma świadomość, że Trybunał Konstytucyjny w wyroku z 7 czerwca 2016 r. (sygn. akt K 8/15) zdyskwalifikował ingerencję ustawodawcy, na podstawie której wykluczono możliwość dostępu w trybie ustawy o dostępie do informacji publicznej do pytań (zadań) testowych wykorzystanych w egzaminach lekarskich. Sąd konstytucyjny wskazał przy tym, że ograniczenie prawa dostępu do informacji publicznej zostało dokonane, mimo że nie przemawiają za nim żadne $\mathrm{z}$ wartości wymienionych $\mathrm{w}$ art. 61 ust. 3 Konstytucji. W poczynionych wywodach Sejm podjął próbę wskazania ewentualnych wartości przywołanych w art. 61 ust. 3 Konstytucji, które mogłyby stanowić podstawę dla dalszych wywodów dotyczących respektowania zasady proporcjonalności z art. 31 ust. 3 ustawy zasadniczej. Brak przydatności kwestionowanej regulacji dla założonych celów uniemożliwia jednak obronę domniemania jej konstytucyjności

8. Uwzględniając poczynione ustalenia, Sejm wnosi o stwierdzenie, że art. $14 \mathrm{c}$ ust. 4 i ust. 5 oraz art. 16rc ust. 6 i ust. 7 u.z.l. są niezgodne $z$ art. 61 ust. 3 w związku z art. 31 ust. 3 Konstytucji.

\section{Bibliografia}

Banaszak B., Konstytucja Rzeczypospolitej Polskiej. Komentarz, Warszawa 2009.

Bernaczyk M., Prawo do informacji publicznej w Polsce i na świecie, Warszawa 2014.

Garlicki L., Komentarz do art. 191 [w:] Konstytucja Rzeczypospolitej Polskiej. Komentarz, t. V, red. L. Garlicki, Warszawa 2007.

Preiss W. [w:] Ustawa o zawodach lekarza i lekarza dentysty. Komentarz, red. E. Zielińska, Warszawa 2014. 